PostgRad. MED. J. (1964), 40, 727

Case Report

\title{
BENIGN INTRACRANIAL HYPERTENSION
}

\author{
R. P. Jayewardene, M.D., M.R.C.P. \\ Faculty of Medicine, University of Ceylon, Colombo.
}

A MARKED increase of intracranial pressure may sometimes be present without a localised space occupying mass. The symptoms suggest an intracranial tumour but there are no localising symptoms or signs. Since neurological and neurosurgical examination do not reveal a tumour the syndrome has been called "pseudo-tumour cerebri" or "benign intracranial hypertension". Although the syndrome was first described by Quincke in 1893, its etiology and pathology are still uncertain. From time to time the syndrome has received various names such as serous meningitis, meningeal hydrops, toxic and otitic hydrocephalus. Symonds $(1931,1937)$ thought the raised intracranial pressure was caused by the venous obstruction following dural sinus thrombosis in middle ear and mastoid disease. Hence the name "otitic hydrocephalus".

Since the syndrome is sometimes associated with upper respiratory infections (McAlpine, 1937), acute infective polyneuritis (Ford and Walsh, 1943) and poliomyelitis (Gass, 1957), it has been termed "toxic hydrocephalus". Foley (1955) found it to be more common in women and associated with menstruation and pregnancy. Jefferson (1956) described it in Addison's disease and Dees and McKay (1959) reported three children with the syndrome while being treated for asthma with corticosteroids. Endocrine changes affecting fluid balance may explain the syndrome in these cases.

Headache, dizziness and blurring of vision are the dominant symptoms. Vomiting occurs sometimes. Diplopia is present if there is sixth nerve palsy. Consciousness is not disturbed. Fits do not occur. Papillœdema and a sixth nerve palsy are the only signs. The CSF is normal, but its pressure is raised, being $300-500 \mathrm{~mm}$. Ventriculography shows normal or small ventricles without displacement. Carotid arteriograms are normal. After repeated lumbar punctures the CSF pressure returns to normal and the papillœdema subsides with restoration of vision to normal in a few weeks or months.

Three cases treated in a medical ward of the General Hospital, Colombo, are reported.

\section{Case 1}

A.S., male, 45 years old was seen on April 25th, 1961. He complained of headache of rapid onset, with specks of light before his eyes. The headache was worse at night and on coughing. Dimness of vision and diplopia were occasionally present.
Duration was about three weeks. There was no history of trauma, discharge from the ear or vertigo. He was intelligent and his speech was normal and memory good.

On examination. The heart, lungs and abdomen were normal and the B.P. was $130 / 90 \mathrm{~mm}$. Hg. The CNS examination showed impaired vision and bilateral papillodema with a few hæmorrhages. The motor and sensory systems were normal. There were no cerebellar signs. Reflexes were normal. X-ray of skull showed some erosion of the dorsum sellæ. Air ventriculography was done. The CSF was not under tension in the ventricles and on examination was blood stained. CSF showed: RBC $1500 \mathrm{mg} . / \mathrm{cu}$. mm., lymphs 6/ cu. mm., protein $18 \mathrm{mg} . / 100 \mathrm{ml}$., sugar $80 \mathrm{mg} . / 100$ ml., chlorides $725 \mathrm{mg}$. $/ 100 \mathrm{ml}$. The ventriculogram showed ventricles of normal size without distortion or displacement. Lumbar-puncture was done on May 8th, 1961. The CSF pressure was $255 \mathrm{~mm}$. in the prone position. It was reduced to $155 \mathrm{~mm}$. The CSF report was protein $35 \mathrm{mg}$./ $100 \mathrm{ml}$., chlorides $725 \mathrm{mg}$./ $100 \mathrm{ml}$., lymphs $5 / \mathrm{cu}$. mm. The papillodema was subsiding and the vision less blurred so the next lumbar-puncture was done a week later. CSF pressure was then $180 \mathrm{~mm}$. and the protein $40 \mathrm{mg}$. $/ 100 \mathrm{ml}$., chlorides $725 \mathrm{mg}$. $100 \mathrm{ml}$., lymphocytes 1 per cu. mm. The patient was discharged from hospital 3 days later free from headache. He was seen regularly at the neurosurgical out-patients, and was last seen by me on September 9th, 1963 when he was fit and well, his vision and ocular-fundi were normal.

Case 2

S.R.D., male, 17 years was seen on January 8th, 1963. He complained of frontal headache and blurring of vision for 2 months. The headache was continuous. There was no vomiting. The blurring of vision started in the right eye and later affected the left. There were no fits. There was no history of head injury, discharge from the ears, ataxia or vertigo.

On examination he was well nourished. The heart, lungs and abdomen were normal, B.P. $130 / 90 \mathrm{~mm}$. $\mathrm{Hg}$. CNS examination showed:- Intelligence and memory good, hearing and speech normal, vision poor in both eyes, only hand movements were seen, bilateral papillœdema + . Other cranial nerves normal and the motor and sensory systems normal, cerebellar signs nil. The reflexes were normal. X-ray of skull showed calcification of pineal gland; no evidence of a space occupying lesion.

Eye surgeon's report on January 1st, 1963: “The right disc appears normal but the left shows some swelling. It is likely that a pre-existing odema is now subsiding. Possible cause (1) Otitic hydrocephalus or benign intracranial hypertension (2) Space occupying mass which has shifted its position". Lumbar puncture:-CSF pressure $380 \mathrm{~mm}$. Compression of jugular veins raised the pressure to $420 \mathrm{~mm}$. 
CSF report-lymphs $80 / \mathrm{cu}$. mm., polys $2 / \mathrm{cu} . \mathrm{mm}$; protein $35 \mathrm{mg}$. $/ 100 \mathrm{ml}$, chloride $702 \mathrm{mg} . / 100 \mathrm{ml}$. sugar $81 \mathrm{mg} . / 100 \mathrm{ml}$. CSF Kahn and VDRL tests negative. The vision improved slowly and the headache was less after the lumbar puncture. A week later the CSF pressure was $380 \mathrm{~mm}$. This was reduced to $200 \mathrm{~mm}$. Vision: right, eye $3 / 60$; left hand movements only. The left showed papillœdema. The vision improved steadily. By the end of the week the patient was able to read the newspaper and there was no papillodema.

The patient refused further investigation and left hospital. He was seen three months later at the outpatients clinic and was admitted to hospital for pain in the right hip and difficulty in walking. Examination of the nervous system did not reveal any abnormality, vision was normal. The fundi were quite normal. The eye surgeon reported "the discs are back to normal" X-ray of the pelvis and lumbar spine showed no fracture or any other abnormality. He left hospital after nine days without any disability. This patient was seen at the out-patients clinic on October 19th, 1963. He was fit and well. The fundi and CNS were normal.

\section{Case 3}

C.S., male, 18 years, was sent to the General hospital, Colombo on May 4th, 1963, for treatment of a cerebral tumor. He complained of headache, blurring of vision and mental confusion off and on for one month. There was no history of vomiting, fits, head injury, discharge from the ears or vertigo. On Examination General physical examination was normal. Heart, lungs and abdomen normal, B.P. $110 /$ $70 \mathrm{~mm}$. Hg. CNS examination showed bilateral sixth nerve weakness and papillœdema with some exudates. The other cranial nerves and systems were normal. X-ray of skull showed some decalcification of the dorsum sellæ. Ventriculogram showed small lateral ventricles with 3rd and 4th ventricles and aqueduct in midline; the ventricular fluid was blood stained. Lumbar puncture two days later:- CSF pressure greater than $400 \mathrm{~mm}$. This was reduced to $150 \mathrm{~mm}$. CSF : lymphs $30 / \mathrm{cu}$. mm., polys $10 / \mathrm{cu}$. mm., protein $20 \mathrm{mg} . / 100 \mathrm{ml}$, chloride $667 \mathrm{mg} . / 100 \mathrm{ml}$,, sugar $74 \mathrm{mg} . / 100 \mathrm{ml}$.

Two days later the CSF pressure was still greater than $400 \mathrm{~mm}$. and it was reduced to $150 \mathrm{~mm}$. A carotid arteriogram showed no distortion of the cerebral arteries. An EEG showed no evidence of a tumour. Lumbar puncture was done every other day and the CSF pressure gradually reduced from over $400 \mathrm{~mm}$. to $220 \mathrm{~mm}$. after one month. The headache was much less and the vision slowly improved. The patient was soon able to read the newspaper.

Eye surgeon's report (June 27th, 1963), Bilateral papillœdema. CSF examination on July 6th, 1963,lymphs $5 / \mathrm{cu}$. mm., polys, $1 / \mathrm{cu}$. mm., protein $20 \mathrm{mg}$./ $100 \mathrm{ml}$., chloride $667 \mathrm{mg} . / 100 \mathrm{ml}$. pressure $320 \mathrm{~mm}$. On August 4th, 1963, the vision was $6 / 6$ in each eve and the right disc was free of swelling, though the left was still swollen. On August 9th, 1963, the CSF pressure was $330 \mathrm{~mm}$. It was reduced to $200 \mathrm{~mm}$. After this the headache was much less. The patient left hospital and returned after one month. He still complained of headache but was otherwise quite normal. On September 24th, 1963, the CSF pressure was $400 \mathrm{~mm}$. and it was reduced to $200 \mathrm{~mm}$. The fundi were normal and the vision $6 / 6$ in both eyes. Lumbar puncture was done twice and the pressure reduced to, $200 \mathrm{~mm}$. When he left hospital he stip had a slight headache but was otherwise normal. Tif CSF pressure was $335 \mathrm{~mm}$.

\section{Discussion}

It is possible for the intracranial pressure to rise high enough to cause severe papilloedema and loss of vision without any demonstrable intracrania disease. The symptoms are few, namely hea ache, blurring of vision and diplopia and the physical signs only papillœdema and a high intro cranial pressure, with a sixth nerve palsy occs sionally. The negative features, namely the absence of any localising symptoms and signs, are ins portant for diagnosis. Ventriculography and carotoid arteriography must be done to exclude a cerebral tumour. The treatment aims at redues tion of the intracranial pressure by repeated lumbar puncture. Subtemporal decompression ma be necessary if the papillodema persists and the.e. is a danger of optic atrophy. Response to lumbate puncture may be rapid as in Cases 1 and 2, om much slower as in Case 3. The diagnosis in Case 2 is based on the rapid response to treatment and the fast that the patient is fit and well 10 months after he was treated in hospital.

The intracranial hypertension has been ex, plained by increased production or decreased absorption of cerebrospinal fluid following durag venous sinus thrombosis. This seems improbabeg since the ventricular system is normal or smate than normal in most cases. In the absence of venous sinus thrombosis the intracranial hy tension may be produced by cerebral odem following vascular dilatation or fluid retenton from electrolyte imbalance in endocrine disorders The white matter may undergo swelling fror intracellular and interstitial cedema in a numbes of conditions such as head injury, infection an tumour. This œdema may develop rapidly and subside slowly without any destruction of brain tissue. Hence the complete recovery even aftes several months. The papillodema is probably an extension of the odema along the sheath of th optic nerve. It is usually present when the pressure is high. But there was no trace of it in Case when the pressure was still $335 \mathrm{~mm}$. The odem may have receded from the optic nerve and pero mitted better venous drainage, relieving the papillœdema though the cerebral œdema per sisted and the CSF pressure was high.

Since the mechanism by which the odema is produced remains obscure, the only demonstrable abnormality is the intracranial hypertension, and recovery, even if it is slow, is eventually complete The name "Benign Intracranial Hypertension' seems to be the most suitable. In most cases recovery is spontaneous and lumbar puncture is the only treatment necessary. Surgical decomprest sion may become necessary when the pressure io persistently high and optic atrophy is threatened

At the Neurosurgical Unit, General Hospita Colombo, sixteen patients have been investigate 
and diagnosed as having benign intracranial hypertension. Three of these patients have been treated surgically because the CSF pressure remained high after several lumbar punctures and optic atrophy was threatened. The Nulsen-Spitz ventriculo-cardiac shunt using a Holter valve, the method used for the relief of hydrocephalus, has been the procedure on these patients. They are free of symptoms and keeping well, one year after the operation (Weinman, 1963).

\section{Summary}

Intracranial hypertension with papillœdema, a normal ventricular system and normal cerebrospinal fluid, has been referred to as "Otitic or toxic hydrocephalus" and "pseudo-tumour cerebri"”.

Since cerebral œdema of obscure origin may be the cause of the hypertension and complete recovery is the rule, "Benign Intracranial Hypertension" appears to be the better name for the syndrome.

Three cases of the syndrome are described. All three recovered after lumbar puncture.

Indications for surgery and a method of surgical treatment are mentioned.

\section{REFERENCES}

Dees, S. C., and McKaY, H. W. (1959): Occurrence of Pseudotumor Cerebri (Benign Intracranial Hypertension) during Treatment of Children with Asthma by Adrenal Steroids, Pediatrics, 23, 1143.

Foley, J. (1955): Benign Intracranial Hypertension, Brain, 78, 1.

FORD, F. R., and WALSH, F. B. (1943): Guillain-Barré Syndrome (Acute Infective Polyneuritis) with Increased Intracranial Pressure and Papilloedema, Bull. Johns Hopk. Hosp., 73, 391.

BRADSHAW, P. (1956): Benign Intracranial Hypertension, J. Neurosurg. Psychiat., 19, 28.

GASS, H. H. (1957): Papilloedema and Pseudotumor Cerebri following Poliomyelitis, J. Dis. Child., 93, 640.

MCAlPINE, D. (1937): Toxic Hydrocephalus, Brain, 60, 180.

SYMONDS, C. P. (1931): Otitic Hydrocephalus, ibid, 54, 55.

(1937): Hydrocephalic and Focal Cerebral Symptoms in Relation to Thrombophlebitis Dural Sinuses and Cerebral Veins, ibid, 60, 531.

Weinman, D. F. (1963): Personal Communication. 